\title{
Could a new record change the range of distribution of a little - known bat species (Vespertilionidae: Eptesicus innoxius)?
}

\author{
Christian R. Loaiza S. ${ }^{*}$, Jaime A. Salas ${ }^{2,3}$, and Andrea Au Hing ${ }^{2}$ \\ ${ }^{1}$ Departamento de Mastozoología, Museo de Historia Natural, Universidad Nacional Mayor de San Marcos, Av. Arenales 1256, \\ Jesús María, Lima, Perú. Email: christian.loaiza@unmsm.edu.pe (CRLS). \\ ${ }^{2}$ Universidad de Guayaquil, Facultad de Ciencias Naturales, Museo de Zoología (MZUG). Campus Mapasingue, Av. Juan Tanca \\ Marengo s/n y Raúl Gómez Lince, Ecuador. Email: jaime.salasz@ug.edu.ec (JAS), andau92@hotmail.com (AAH). \\ ${ }^{3}$ Universidad Espíritu Santo, Km. 2.5 de la vía a Samborondón, Guayaquil, Ecuador. \\ *Corresponding author
}

We report the first record of Eptesicus innoxius in northwestern Ecuador, in the province of Esmeraldas, occurring in a disturbed area, at 134.3 $\mathrm{km}$ northwest from the nearest known locality in Ecuador, which represents an important latitudinal extension in the distribution of this species. A predictive distribution model is presented using a total of 43 records from localities of Ecuador and Perú, and its distribution area is determined by a minimum convex polygon (PMC). The sensitivity value obtained in the test data was 0.984 and the area under curve ROC (AUC) value obtained (0.979) indicates an acceptable confidence level. Based on new records and known records, we estimate its distribution area in 135,243 km². The environmental variables with the greatest influence in the distribution of $E$. innoxius were: Precipitation seasonality (37.4 \%), minimum temperature of coldest month (20.1\%), precipitation of driest month (14.5\%), and mean temperature of wettest quarter (12.8\%). This data show that $E$. innoxius has been recorded mainly in tropical dry forest, but also has presence in humid areas. Within these new reports, we recommended an upgrade of its conservation status in Ecuador and Perú.

Se presenta el primer registro de E. innoxius al noroccidente de la costa ecuatoriana, en la provincia de Esmeraldas, dentro de una zona alterada, a $134.3 \mathrm{~km}$ noroeste del registro conocido más cercano en Ecuador, el cual representa una importante extensión en la distribución latitudinal conocida para esta especie. Se realizó un modelamiento predictivo de su distribución, utilizando un total de 43 registros de localidades presentes en Ecuador y Perú, y se determinó su área de distribución mediante el método del polígono mínimo convexo (PMC). El valor de sensibilidad obtenido en la prueba fue de 0.984 y el valor del área bajo la curva (AUC) fue de 0.979 , lo cual indica un nivel de confianza aceptable. El área de distribución obtenida en base a los registros utilizados fue de 135,243 km². Las variables ambientales con mayor influencia en la distribución de E. innoxius fueron: estacionalidad de la precipitación (37.4 \%), temperatura minima del mes más frío (20.1 \%), precipitación del mes más seco (14.5\%), y temperatura media del cuatrimestre más lluvioso (12.8\%). De acuerdo con los registros, esta especie habita preferentemente en zonas de bosque seco, pero puede llegar a habitar en zonas de transición con mayor humedad. Basándonos en los nuevos registros obtenidos, se recomienda realizar una nueva evaluación de su estado de conservación en Ecuador y Perú.

Key words: Extension distribution; harmless serotine bat; northwestern Ecuador; predictive model.

(c) 2020 Asociación Mexicana de Mastozoología, www.mastozoologiamexicana.org

\section{Introduction}

The bats of the genus Eptesicus Rafinesque (1820), are grouped into two subgenera and comprises approximately 18 species (Davis 1966; Corbet and Hill 1980; Hill and Harrison 1987; Simmons 2005; Davis and Gardner 2008). All New World species belong into the nominative subgenus. At a morphological level, species in the genus can be recognized by the absence of hairs in the uropatagium, proximal to the body; internal upper incisors larger than the external, usually with a secondary cusp, and lack of evident space between upper canines and premolars, among other features (Davis 1966; Albuja 1999; Davis and Gardner 2008; Díaz et al. 2016).

Eptesicus innoxius (Gervais 1841) is one of the smallest species within the genus, and is distributed on the western slope of the Andes, from southwestern Ecuador, in the provinces of Bolívar, Cotopaxi, Guayas, Los Ríos, Santo Domingo, El Oro and Loja, and northern Perú, between the departments of Tumbes, Piura and Lambayeque (Koopman 1978; Albuja 1999; Cadenillas et al. 2007; Pacheco et al. 2007; Pacheco et al. 2009; Davis and Gardner 2008; Carrera et al. 2010; Tirira 2017). It can be easily recognized by its size (forearm 34 to $39 \mathrm{~mm}$ ), small skull (13.9 to $15.8 \mathrm{~mm}$ ), and sagittal and lambdoidal crests poorly defined or absent (Davis 1966; Tirira 2017).

The type locality is located in the region of Amotape, Piura (Perú) in the ecological region known as Equatorial dry forest (Gervais 1841; Davis and Gardner 2008; Pacheco et al. 2009). Historical records of this species in Ecuador and Perú are located in Babahoyo (Los Ríos) and Puerto Etén (Lambayeque; Cabrera 1901; Davis 1966; Davis and Gardner 2008). Within Ecuador, its distribution includes dry tropical and subtropical forests (Bolívar, Guayas, Los Ríos, and El Oro) and some deciduous and semideciduous dry forest, while in Perú its distribution comprises the Pacific rainforest, Equatorial dry forest, and Coastal desert (Cabrera 1901; Davis 1966; Albuja 1999; Pacheco et al. 2009; Carrera et al. 2010; Burneo and Tirira 2014; Tirira 2017, Brito et al. 2018). Elevational range is 0 to $900 \mathrm{~m}$ (Tirira 2017), but there are some records in Loja and El Oro Provinces (Ecuador) and other localities in Perú above 1,000 m (Appendix 1). 
Species distribution modeling have been developed to generate potential presence maps based on the concept of fundamental niche so that they can include areas with limited collection efforts (Stockwell and Peters 1999). The resulting predictive models have been widely used in studies of diversity, ecology and biogeography (Burneo et al. 2014; Burneo et al. 2015; Giménez et al. 2015; Loaiza and Pacheco 2017). Among the methods currently used to obtain the modeling of the species distribution is Maxent (Phillips et al. 2006), that estimates the probability of occurrence distribution of species, following the principle of maximum entropy, subject to the condition that the expected value of each environmental variable coincides with its empirical mean (Phillips et al. 2006; Merow et al. 2013). Among the various applications of Maxent are the prioritization of areas for initiatives of biological conservation end ecological restoration, modeling the effects of climate change on ecosystems, and the evaluation of patterns of propagation of invasive species (Phillips and Dudík 2008; Morales 2012).

The objective of this study is to propose a model for the geographical distribution of this species based on recently records obtained in the Ecuadorian provinces of Esmeraldas, Guayas and Los Ríos, as well as to review its threat status in Ecuador and propose conservation actions for this species.

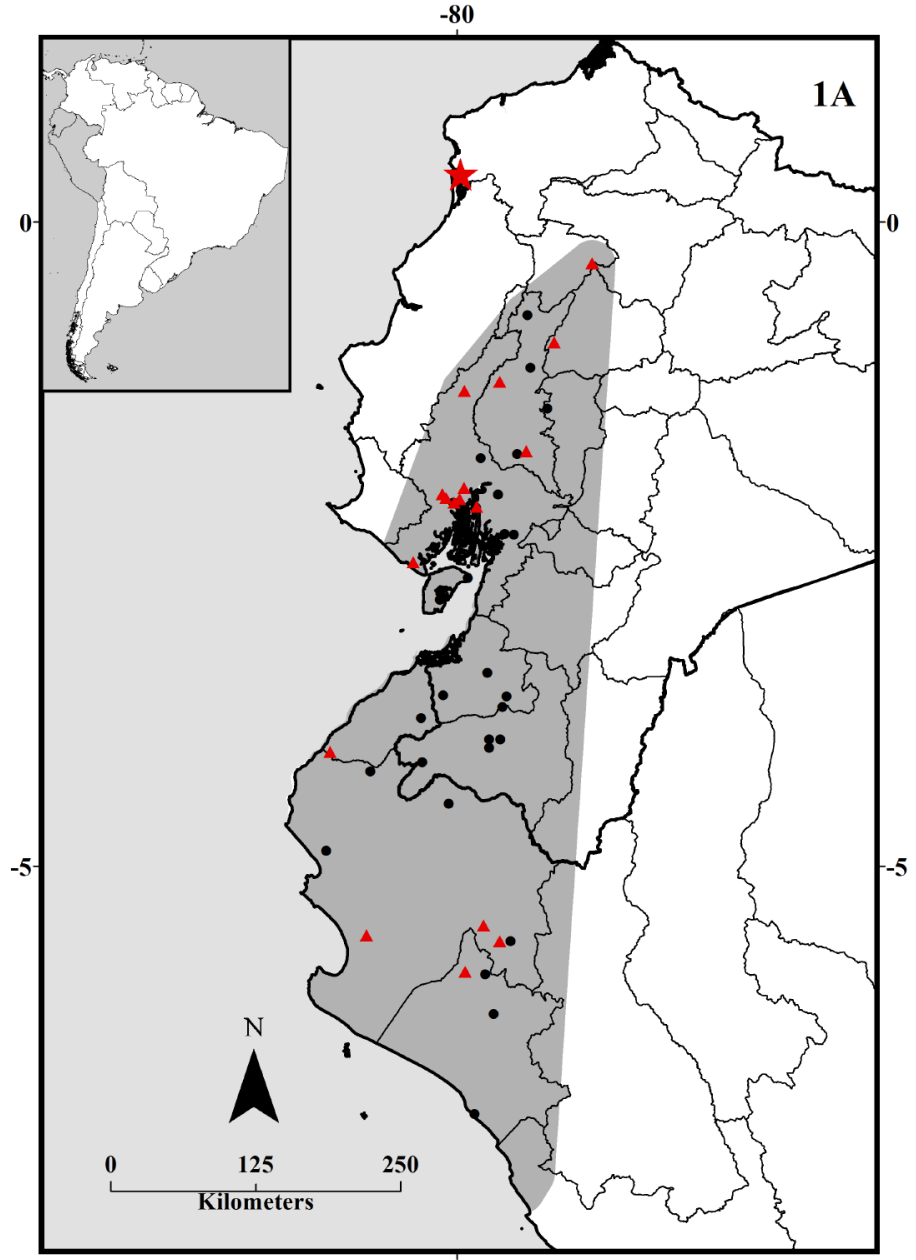

$-80$

\section{Materials and methods}

Field work. The collection locations (Figure $1 \mathrm{~A}$ ) were as follows: 1) Esmeraldas province: Recinto Pedro Carbo ( $-0^{\circ} 22^{\prime} \mathrm{S}$, $-79^{\circ} 58^{\prime} \mathrm{W}$ ), sampled during January 2016 , in rainy season, on a strongly fragmented area, with African oil palm plantations, the field work was carried out in a transition zone between mangrove and humid forest. 2) Guayas province: Bosque Protector La Prosperina $\left(-2^{\circ} 08^{\prime} \mathrm{S},-79^{\circ} 58^{\prime} \mathrm{W}\right)$, and Bosque Protector Cerro Blanco $\left(-2^{\circ} 08^{\prime} \mathrm{S},-80^{\circ} 05^{\prime} \mathrm{W}\right)$, both were sampled between January 2016 until March 2017 (rainy season); and Cerro del Muerto $\left(-2^{\circ} 38^{\prime} \mathrm{S},-80^{\circ} 20^{\prime} \mathrm{W}\right)$, sampled during May to August 2018 (dry season), all three privately owned, surrounded by intervened secondary tropical and dry forest areas; Area Nacional de Recreación Isla Santay $\left(-2^{\circ}\right.$ $12^{\prime} \mathrm{S},-79^{\circ} 50^{\prime} \mathrm{W}$ ), sampled during May to June 2018 (dry season), a protected area under the supervision of the Ministry on Environment of Ecuador, with mangroves, xerophilous scrub and wetlands ecosystems. 3) Los Ríos province: Cerro Cacharí $\left(-1^{\circ} 46^{\prime} \mathrm{S},-79^{\circ} 27^{\prime} \mathrm{W}\right)$, during February 2017 until February 2018, privately owned, approximately two kilometers from the city of Babahoyo, which has a cave and some cracks in its interior, and maintains relicts of dry forest. All the captures were made with mist nets located at ground and sub canopy level. We used four mist - nets each night in

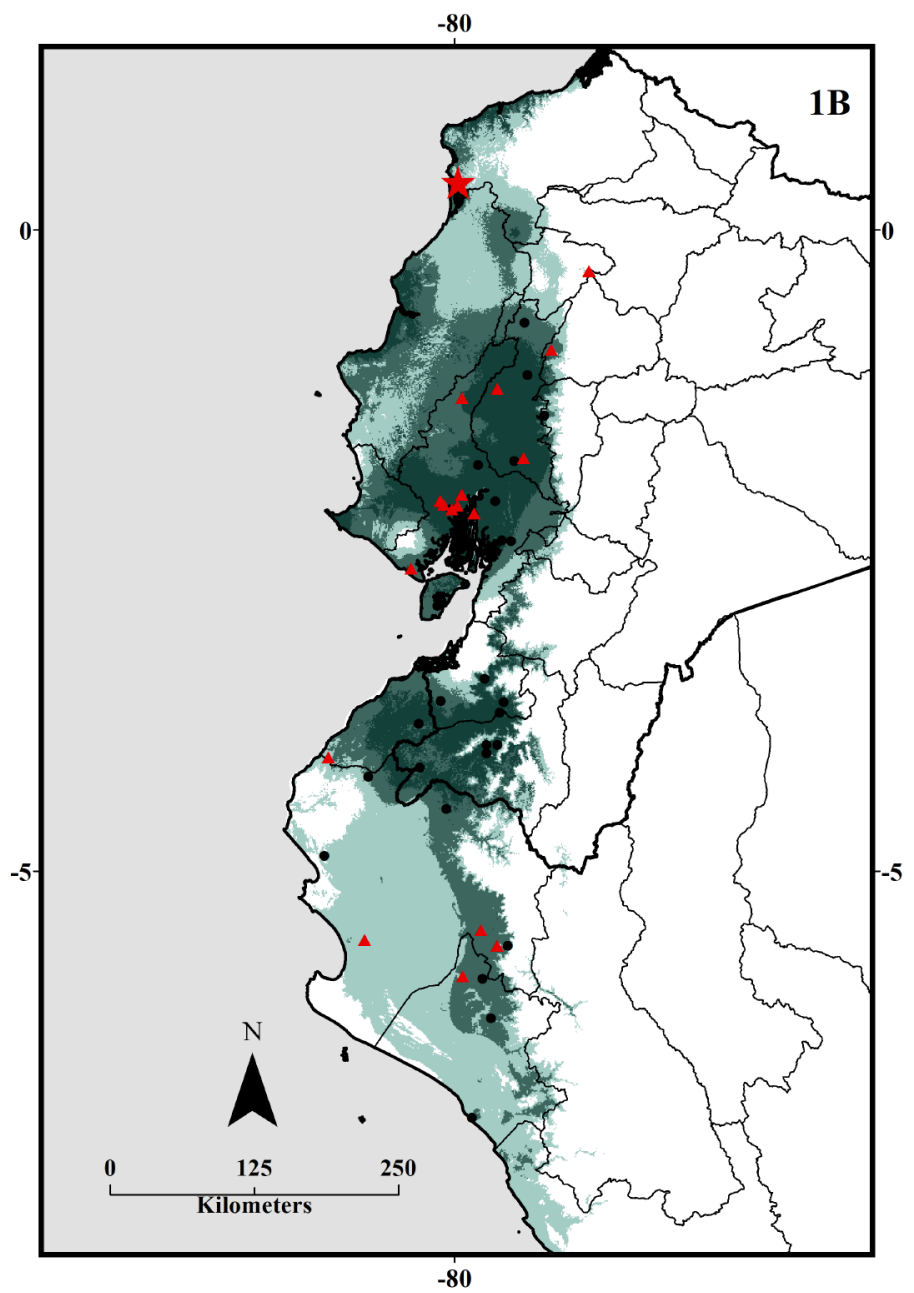

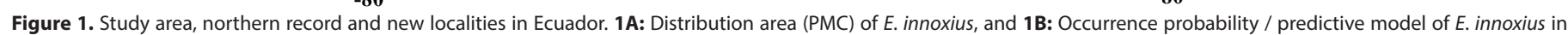

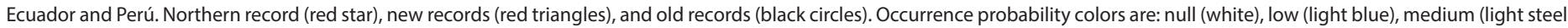
blue), high - medium (steel blue), and high (dark blue). 
each locality, from 18 to $23 \mathrm{~h}$, which were checked every fifteen minutes. Nets were placed at ground level and in subcanopy level, until reaching a height between 4 to 5 meters and were changed from location each time to prevent bats become familiar with them.

Additional locations. The study sites (Figure 1A) and other localities correspond to protected areas and forests of Guayas, Los Ríos and El Oro provinces. Climate is warm with a mean temperature of $25^{\circ} \mathrm{C}$ and a high level of rainfall ranging from 2,500 to $3,000 \mathrm{~m}$. Other localities in Loja and El Oro provinces correspond to dry interandean valleys and areas of deciduous dry forest.

Specimens collected and morphometric analysis. We reviewed seven specimens (three males and four females) deposited in the mammals' collection of the Museum of Zoology (MZUGM), at Universidad de Guayaquil, Facultad de Ciencias Naturales, and their identity was determined by an analysis from taxonomic characters described in the literature (Albuja 1999; Davis and Gardner 2008; Tirira 2017). The measurements were taken according to Carrera et al. (2010) and Díaz et al. (2016). External and cranial measurements were recorded for all specimens (Table 1). The nomenclature is as follows: total length (TL), body and head length $(H B)$, tail length $(T)$, ear length $(E)$, forearm length $(F A)$, hind foot length (HF), greatest length of skull (GLS), condylobasal length $(\mathrm{CBL})$, braincase height $(\mathrm{BBH})$, braincase breadth (BBC), zygomatic breadth (ZB), mastoid breadth (BM), postorbital constriction $(\mathrm{POC})$, and palate length $(\mathrm{PL})$.

Distributive modeling. We modeled the potential distribution of this species using the Maximum Entropy niche model (Maxent), which allows an estimate of the probability of occurrence of a species approximating the distribution of maximum entropy (Phillips et al. 2006; Phillips and Dudík 2008; Morales 2012; Merow et al. 2013).

To obtain the model, we proceeded to download the environmental variables of World Clim (www.worldclim.org), which comprise different types of bioclimatic factors in raster format. The 30s bioclimate file were downloaded in ESRI grid format ( $1 \mathrm{~km})$ and a cutout of the variables for Ecuador and Perú was carried out. The set of environmental variables obtained has eleven temperature variables and eight precipitation variables (19 bioclimatic variables) in order to generate variables with biological significance. The 19 variables represent annual trends, seasonality and extreme environmental factors detailed in Table 3. The digital environmental layers were used to obtain the potential distribution.

A total of 43 records were used to define the potential distribution, including: 7 records obtained during latest fieldwork, 18 obtained from the main museums of Ecuador and Perú, and 18 from databases belonging to natural history museums (Table 2). We applied the methodology described in Giménez et al. (2015), which consists in developing 10 replicas for the model, with $25 \%$ of the records used as test data, 500 iterations and 10,000 background points in order to obtain a high precision in the modeling.
Table 1: External and descriptive measures of E. innoxius. The measurements are expressed in $\mathrm{mm}$, the abbreviation is detailed in material and methods section. Observed range (above) mean and standard deviation (below).

\begin{tabular}{|c|c|c|c|c|c|}
\hline \multirow[t]{2}{*}{ Measures } & \multicolumn{2}{|c|}{ Davis (1966) } & \multirow{2}{*}{$\begin{array}{c}\text { Tirira (2017) } \\
\text { Combined sexes }\end{array}$} & \multirow{2}{*}{ 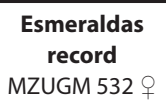 } & \multirow{2}{*}{$\begin{array}{c}\text { This study } \\
34\end{array}$} \\
\hline & $4 \hat{O}$ & $13 q$ & & & \\
\hline TL & - & - & - & 75 & $\begin{array}{c}68-77 \\
75.1 \pm 4.81\end{array}$ \\
\hline $\mathrm{HB}$ & - & - & $53-54$ & 43 & $\begin{array}{c}40-55 \\
46.5 \pm 4.86\end{array}$ \\
\hline $\mathrm{T}$ & - & - & $36-38$ & 26 & $\begin{array}{c}24-34 \\
29.4 \pm 3.82\end{array}$ \\
\hline$E$ & - & - & $10-14$ & 12 & $\begin{array}{c}7-12 \\
10.3 \pm 1.98\end{array}$ \\
\hline FA & $\begin{array}{c}35.3-38.5 \\
36.7\end{array}$ & $\begin{array}{c}34.0-38.7 \\
37.0\end{array}$ & $34-40$ & 37 & $\begin{array}{c}35-39 \\
37.1 \pm 1.35\end{array}$ \\
\hline HF & - & - & $8-10$ & 5 & $\begin{array}{c}4-8 \\
6.1 \pm 1.57\end{array}$ \\
\hline GLS & $\begin{array}{c}14.3-15.6 \\
14.9\end{array}$ & $\begin{array}{c}13.9-15.8 \\
15.1\end{array}$ & - & 15.87 & $\begin{array}{l}13.92-15.87 \\
14.87 \pm 0.69\end{array}$ \\
\hline CBL & - & - & - & 13.62 & $\begin{array}{l}12.53-13.62 \\
12.95 \pm 0.47\end{array}$ \\
\hline $\mathrm{BBH}$ & - & - & - & 6.88 & $\begin{array}{c}5.82-6.6 \\
6.24 \pm 0.26\end{array}$ \\
\hline BBC & $\begin{array}{c}6.5-7.3 \\
6.85\end{array}$ & $\begin{array}{c}6.5-7.1 \\
6.9\end{array}$ & - & 6.88 & $\begin{array}{l}6.88-7.65 \\
7.20 \pm 0.25\end{array}$ \\
\hline ZB & $\begin{array}{c}8.8-9.6 \\
9.3\end{array}$ & $\begin{array}{c}8.9-10.0 \\
9.55\end{array}$ & - & 9.64 & $\begin{array}{l}8.19-9.88 \\
9.23 \pm 0.60\end{array}$ \\
\hline BM & - & - & - & 7.48 & $\begin{array}{l}7.02-7.96 \\
7.54 \pm 0.34\end{array}$ \\
\hline POC & - & - & - & 4.06 & $\begin{array}{l}3.93-4.72 \\
4.20 \pm 0.27\end{array}$ \\
\hline PL & - & - & - & 7.6 & $\begin{array}{l}6.84-8.28 \\
7.36 \pm 0.50\end{array}$ \\
\hline
\end{tabular}

This methodology was applied to make a jackknife and determine the environmental variables that best contributed to the model. After that, the model was replicated and a logistic model was selected as a grid file, in order to determine the areas with the highest probability of occurrence of this species. As a cut-off threshold, the minimum training presence option was selected, which is often recommended for species with a wide geographical distribution.

To estimate the habitat area of E. innoxius, we used an extension available for ArcGis called Xtools Pro, which allows to create polygons based on the records of a species, and to estimate its habitat in $\mathrm{km}^{2}$ (https://xtools.pro/). The final maps were made with the ArcGis 10.3 program (ESRI 2014).

Table 2: Number of specimens used in the predictive niche modeling retrieved and verified in literature and Global Biodiversity Information Facility: GBIF (www.gbif.org)

\begin{tabular}{llr}
\multicolumn{1}{c}{ Acronym } & \multicolumn{1}{c}{ Museum } & Specimens \\
\hline AMNH & American Museum of Natural History & 4 \\
EBD & Estación Biológica de Doñana & 1 \\
FMNH & Field Museum of Natural History & 1 \\
LSUMZ & Lousiana State University Museum & 3 \\
MEPN & Museo de la Escuela Politécnica Nacional & 1 \\
MSU & Michigan State University Museum & 1 \\
MUSM & Museo de Historia Natural de San Marcos & 6 \\
MNHN & Museum National d'Histoire Naturelle & 1 \\
MZUGM & Museo de Zoología, Universidad de Guayaquil & 7 \\
QCAZ & Museo de Zoología, Quito (PUCE) & 11 \\
TCWC & Texas University Biodiversity Research & 1 \\
TTU & Museum of Texas Tech University & 4 \\
USNM & National Museum of Natural History, Smithsonian & 2 \\
\hline
\end{tabular}




\section{Results}

The morphological characteristics of the new specimens registered in the Ecuadorian coast, as well as the record obtained in the province of Esmeraldas (MZUGM 00532; Figure 2), fully agree with the diagnostic characteristic provided for the species by Davis (1966), Albuja (1999), and Díaz et al. (2016). Measurements provided by Tirira (2017), were inconsistent with the morphometry of $E$. innoxius (Table 1). The measures for males and females according to 18 specimens ( $4 \mathrm{M}, 14 \mathrm{~F})$ are:

Males: $\mathrm{TL}=74$ to $85, \mathrm{HB}=47$ to $55, \mathrm{FA}=36$ to $38, \mathrm{E}=7$ to $15.3, \mathrm{~T}=32$ to $36.1, \mathrm{HF}=4$ to $8, \mathrm{GLS}=13.92$ to $15.20, \mathrm{CBL}$ $=12.60$ to $13.19, \mathrm{BBC}=7.19$ to $7.65, \mathrm{ZB}=8.74$ to $9.88, \mathrm{BM}=$ 7.02 to $7.62, \mathrm{POC}=3.93$ to 4.11 , and $\mathrm{PL}=6.84$ to 8.28 .

Females: $\mathrm{TL}=68$ to $94, \mathrm{HB}=40$ to $53, \mathrm{FA}=33$ to $39, \mathrm{E}=$ 9 to $15, \mathrm{~T}=24$ to $39, \mathrm{HF}=7$ to $10, \mathrm{GLS}=14.51$ to $15.87, \mathrm{CBL}$ $=12.31$ to $13.62, \mathrm{BBC}=6.88$ to $7.31, \mathrm{ZB}=8.19$ to $9.65, \mathrm{BM}=$ 7.48 to $7.96, \mathrm{POC}=4.06$ to 4.72 , and $\mathrm{PL}=6.96$ to 7.53 .

Geographic distribution. The specimen of Eptesicus innoxius from Recinto Pedro Carbo (Muisne, Esmeraldas), is located at $134.3 \mathrm{~km}$ northwest from the northernmost known record, at Recinto Corriente Grande (Los Ríos), and constitutes the first report for the province of Esmeraldas (Davis and Gardner 2008; Tirira 2008; Burneo and Tirira 2014; Tirira 2017). The locality of Recinto Pedro Carbo is located near a mangrove area at an altitude of $13 \mathrm{~m}$, within the floristic formation known as evergreen lowland forest of the coast (Ministerio de Ambiente del Ecuador 2013), between the northwestern and southwestern tropical zoogeographic regions (Albuja et al. 2012). Other localities reported for $E$. innoxius are located in the southwestern tropical and western subtropical regions (Albuja 1999; Tirira 2017).

In Perú, 11 localities were located in the Equatorial dry forest, another locality was in the Pacific rain forest, and only one was located in the Coastal desert, according to the classification system proposed by Brack - Egg (1986; Pacheco et al. 2009). The plant formations assigned to the different localities includes: dry low hill forest, dry mountain forest, and dry savanna forest (Ministerio de Ambiente del Ecuador 2015).

The potential distribution of $E$. innoxius extends throughout the Ecuadorian coastal and northern - central Perú (Figure 1B). Nevertheless, the areas of greatest importance for its distribution are located mainly in several Ecuadorian coastal provinces (Santa Elena, Guayas, El Oro and Los Ríos; Figure 1B). Although in Manabí province the occurrence probability ranges go from medium to high - medium, no records today confirm its presence here. This species is distributed in Loja province mainly toward areas of tropical dry forest, also occupying important areas within some dry interandean valleys where it reaches its highest altitudinal range.

\section{Discussion}

In Ecuador, Eptesicus innoxius appears to be rare in some localities, but it is usually quite common in others (Brito et
Table 3: Percent contribution (\% C) and permutation importance (PI) of each variable for the potential and logistic modeling.

\begin{tabular}{llrr}
\hline & & \multicolumn{2}{c}{ Modeling } \\
Variables & Description & $\%$ C & PI \\
\hline bio_1 & Annual mean temperature & 0.7 & 0 \\
bio_2 & Mean diurnal range (max temp - min temp) & 1.0 & 0.1 \\
bio_3 & Isothermality (* 100) & 1.5 & 1.0 \\
bio_4 & Temperature seasonality (* 100) & 0.2 & 0.1 \\
bio_5 & Maximum temperature of warmest month & 0.1 & 0 \\
bio_6 & Minimum temperature of coldest month & 20.1 & 35.8 \\
bio_7 & Temperature annual range & 0.1 & 0.1 \\
bio_8 & Mean temperature of wettest quarter & 12.8 & 0 \\
bio_9 & Mean temperature of driest quarter & 0.7 & 2.3 \\
bio_10 & Mean temperature of warmest quarter & 2.7 & 0 \\
bio_11 & Mean temperature of coldest quarter & 0 & 0 \\
bio_12 & Annual precipitation & 0 & 0.3 \\
bio_13 & Precipitation of wettest month & 0 & 0 \\
bio_14 & Precipitation of driest month & 14.5 & 54.2 \\
bio_15 & Precipitation seasonality & 37.4 & 1.9 \\
bio_16 & Precipitation of wettest quarter & 1.8 & 1.1 \\
bio_17 & Precipitation of driest quarter & 4.5 & 0 \\
bio_18 & Precipitation of warmest quarter & 0.6 & 0.4 \\
bio_19 & Precipitation of coldest quarter & 1.3 & 2.8 \\
\hline \multirow{2}{*}{ Total } & & & 100 \\
\hline
\end{tabular}

al. 2018; Carrera et al. 2010). This species is present both in natural and protected areas and fragmented or secondary forests, mainly in dry forest and mangrove ecosystems, not in crops or urban environments. Although E. innoxius is considered a typical species of tropical dry forests, it has been recorded in several localities in tropical rain forest such as: Barraganete (Bolívar province, $237 \mathrm{~m}$ ), and Recinto Corriente Grande (Los Ríos province, 88 m; Albuja 1999; Davis and Gardner 2008; Tirira 2017). There was a report from an area dominated by tropical humid forests, based on a specimen collected in the locality of Santa Rosa de Naranjal (Imbabura; QCAZ 10579; Lee et al. 2010). However, it was reidentified as Myotis riparius (Romero 2018).

In Perú, geographic distribution of this species in relation to the probability of presence is not very broad; however, this seems to be associated with the distribution coming from Ecuador (Figure 1B). The most important areas are mainly located in the border of Tumbes and Piura Departments, highlighting an important distribution area within the Lambayeque region. Based on the modeling analysis obtained for this species, the probability of its presence in other regions is quite low. This could be explained due to the fact that $E$. innoxius seems to prefer areas with less extreme climatic conditions and a higher degree of humidity, and therefore has not been able to colonize other regions in Perú.

In Ecuador, E. innoxius is present in a greater variety of ecoregions, including areas of humid and montane forest, mangroves, flooded grasslands, with less presence in dry forest areas, while in Perú, this species has a greater presence in desert and dry forest areas, mainly in the regions of Piura and Lambayeque (Olson and Dinerstein 2002).

The estimated area of distribution was $135,243 \mathrm{~km}^{2}$ (Figure $1 \mathrm{~A})$, which means that the new northwestern record represents a considerable increase with respect to the pre- 


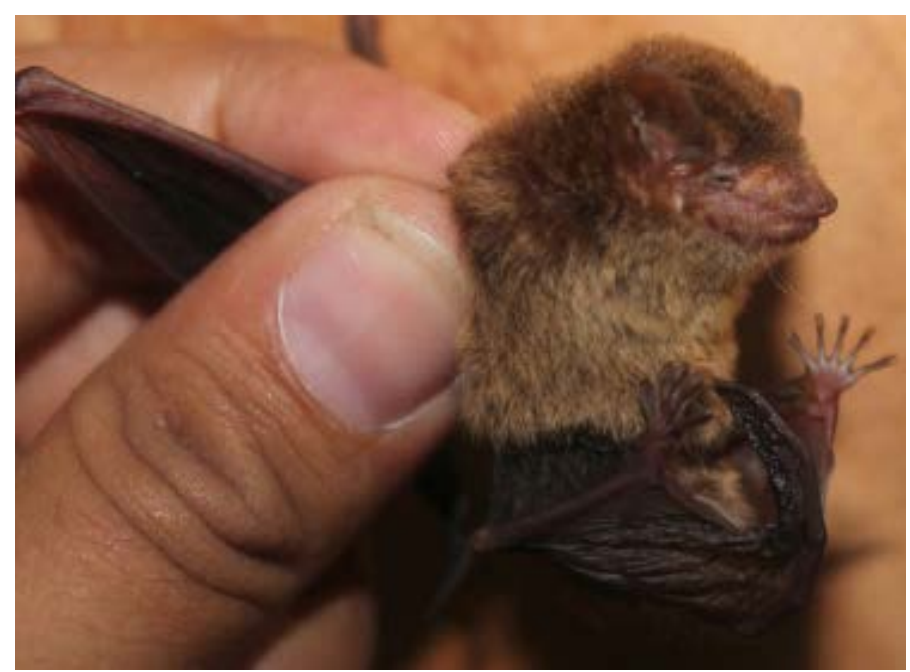

Figure 2. Specimen of E. innoxius (MZUGM 00532) captured in Recinto Pedro Carbo (Esmeraldas) / Photo by Jaime Salas.

viously reported distribution, in transition area between evergreen lowland forest of the coast and mangrove (Davis 1966; Koopman 1978; Albuja 1999; Davis and Gardner 2008; Tirira 2008; Carrera et al. 2010; Burneo and Tirira 2014; Tirira 2017). The results of our modeling coincide with the last distribution map indicated by Tirira (2017) for this species, in relation to the absence of E. innoxius in Manabí. A modeling similar to ours coincides with some zones of highest occurrence probability of E. innoxius in Ecuador (Romero 2018), including the occurrence probability of this species in northern Ecuador; however, that modeling is based on only 11 records and does not include other record localities in Perú.

Conservation status. Earlier evaluations about the conservation status of this species in Ecuador determined that deforestation has caused a considerable reduction of its natural habitat, limiting and restricting its distribution to protected areas, and is currently considered a Vulnerable species (VU) according to criterion B1 ab (i, iii; Tirira and Carrera 2011; Burneo et al. 2015). In IUCN red list, E. innoxius is categorized as Near Threatened (NT; Velazco and Aguirre 2016). Based on the modeling and distribution update carried out in this study (Figure 1) and the new records obtained, an upgrade of its conservation status in Ecuador is recommended, mainly due to the expansion of its distribution area to the northern, in highly fragmented areas.

The majority of records of E. innoxius in Ecuador have been obtained in several protected areas, such as the Bosque Protector Cerro Blanco and Reserva Ecológica Manglares - Churute (Guayas province), Reserva Ecológica Arenillas (El Oro province), and Bosque Petrificado de Puyango (El Oro / Loja provinces; Carrera et al. 2010), as well as in some non-protected areas in Bolívar, Guayas, and Los Ríos (Davis 1966; Koopman 1978; Albuja 1999; Davis and Gardner 2008; Burneo and Tirira 2014). New localities indicated in this study are: Bosque Protector Prosperina (Guayas province, $217 \mathrm{~m}$ ), Cerro Cacharí (Los Rios province, $33 \mathrm{~m}$ ), Cerro del Muerto (Guayas province, $46 \mathrm{~m}$ ), and Area Nacional de Recreación "Isla Santay" (Guayas province, 7 m). In Perú, there is a record in the Coto de Caza "El Angolo", within the biome of Tumbes - Piura dry forest (Cadenillas et al. 2007). Other new localities reported in Perú are: El Abra (Lambayeque, $127 \mathrm{~m}$ ), Laguna Ñapique (Piura, 9 m), Pampa de los Burros (Piura, $735 \mathrm{~m}$ ), Quebrada metida del Zorro (Piura, $327 \mathrm{~m}$ ), and Barrancos (Tumbes, $34 \mathrm{~m}$; Appendix 1).

All these new records indicate the existence of localities that overlap with the zones of greater probability of presence for this species, being possible that $E$. innoxius could be registered in protected areas such as Parque Nacional Machalilla, and Refugio de Vida Silvestre Marino Costera Pacoche (Manabí province), Refugio de Vida Silvestre Manglares - El Morro, and Reserva de Producción Faunística Manglares - El Salado (Guayas province) (Figure 1B). It is necessary to continue monitoring in the area of distribution, and make sure its conservation through inclusion of this species as key species in the management plans of protected areas, or seeking refuges as Important Sites for the Conservation of Bats (SICOM) (Burneo et al. 2015).

In the southern region of Ecuador, some locations where this species has been recorded are currently greatly altered due to deforestation which has decreased much of the original vegetation cover, especially in some dry interandean valleys (Albuja 2011). However, the recent creation of protected areas and forests in Macara and Zapotillo localities (Reserva Natural Cazaderos, La Ceiba y Laipuna) in Loja Province, which are connected to the Reserva de Biosfera del Noroeste Amotapes - Manglares, might ensure protection and its long - term survival.

The distribution area indicated to the north of Perú, in spite of being considered in its majority as an area of lowmedium probability of presence (Figure 1B), is a quite extensive area, with records until the southwest of Lambayeque, for which we consider that the conservation status of this species in Perú is going in the right direction, considering the recent creation of some binational protected areas. However, protected areas that harbor populations of this and other species are still reduced in Ecuador and Perú. A recently published work highlights the importance of the conservation of forests and natural refuges for the bat's conservation on Ecuadorian coast (Linares and Zavala 2018).

It is necessary to carry out studies focused on knowing and determining the population abundance both in Ecuador and in Perú, and other studies about its reproduction cycles, diet, migrations, roost preferences, as well as developing other conservation proposals that will ensure the survival of their populations and the conservation of the different ecosystems where this species lives (Tirira and Carrera 2011).

\section{Acknowledgments}

This work represents a second effort of $C L$ and JAS to update data about the distribution and conservation status of endemic mammals from the dry forests of Ecuador and Perú; it also presents partial results of the undergraduate 
thesis of A. Au Hing (Scientific Research Authorization No. 004-2016-IC-FLO/FAU-DPG/MAE, Cerro El Paraíso), and M. Méndez (Scientific Research Authorization No. MAE-DPALR2017-0234-O, Cerro Cacharí), under the project: Estudios Prioritarios para la Conservación de Mastofauna en la Costa del Ecuador Parte 1: Piso Suroccidental. GIZ Pro-Cambio Program supported the field work in Esmeraldas province, in the framework of the project "Plan de manejo para el uso sustentable y custodia de 152.52 has de bosque de manglar ubicadas en la comunidad de Pedro Carbo del canton Muisne, Esmeraldas por parte de la asociación de pescadores y recolectores de productos del mar-ASOPESCMAR" (Scientific Research Authorization 001-2016-IC-FLO-FAUDPE-MA). JAS express their gratitude to A. Briones, T. Paz, M. Baquerizo and $M$. Méndez for their valuable collaboration during the field work in Esmeraldas, Guayas and Los Ríos, as well as the Biology students of Universidad de Guayaquil: G. Valdiviezo, J. Morales, J. Merchán, A. Campoverde, N. Villacrés, A. Flores, M. B. Potes, C. Balseca, M. Martínez, and $\mathrm{H}$. Moreira, for their assistance in the field work in Cerro del Muerto and Isla Santay (Scientific Research Authorization No. 015-2017-IC-FLO/FAU-DPAG/MAE). We thank anonymous reviewers for making valuable suggestions and improving the English version of the manuscript.

\section{Literature cited}

Albuja, L. 1999. Murciélagos del Ecuador. Escuela Politécnica Nacional. Quito, Ecuador.

Albuja, L. (Ed.). 2011. Biodiversidad de los valles secos interandinos del Ecuador. Escuela Politécnica Nacional. Quito, Ecuador.

Albuja, L., A. Armendáriz, R. Barriga, L. D. Montalvo, F. Cáceres, AND J. L. Román. 2012. Fauna de Vertebrados del Ecuador. Instituto de Ciencias Biológicas. Escuela Politécnica Nacional. Quito, Ecuador.

Brack - EgG, E. 1986. Las ecorregiones del Perú. Boletín de Lima 44:57-70.

Brito, J., C. Garzón, P. Mena, D. González, and J. Mena (eds.). 2018. Mamíferos de la provincia de El Oro: Una guía de identificación de especies de mamíferos del Páramo al Mar. Publicación Miscelánea No. 8: Serie de Publicaciones GADPEO-INABIO. Quito, Ecuador.

Burneo, S. F., AND D. G. TIRIRA. 2014. Murciélagos del Ecuador: un análisis de sus patrones de riqueza, distribución y aspectos de conservación. Therya 5:197-228.

Burneo, S. F., M. D. Proaño, and D. G. TiriRa (eds.). 2015. Plan de acción para la conservación de los murciélagos del Ecuador. Programa para la conservación de los murciélagos del Ecuador. Quito, Ecuador.

Cabrera, A. 1901. Descripción de tres nuevos mamíferos americanos. Boletín de la Sociedad Española de Historia Natural 1:367-373.

Cadenillas, R., M. Alzamora, and F. Abramonte. 2007. Evaluación de Mamíferos. Pp. 28 - 37 in Evaluaciones rápidas de la biodiversidad del Coto de Caza El Angolo. (More, A., ed.). Reporte Técnico \# 2. Naturaleza y Cultura Internacional. Sullana, Perú.
Carrera, J. P., S. Solari, P. A. Larsen, D. F. Alvarado, A. D. Brown, C. Carrión, J. S. Tello, and R. J. Baker. 2010. Bats of the tropical lowlands of western Ecuador. Special Publications, Museum of Texas Tech University 57:1-37.

Corbet, G. B., AND J. E. Hill. 1980. A world list of mammalian species. British Museum (Natural History). London, U.K.

Davis, W. B. 1966. Review of South American bats of the genus Eptesicus. Southwestern Naturalist 11:245-274.

Davis, W. B., and A. L. Gardner. 2008. Genus Eptesicus Rafinesque, 1820. Pp. 440 - 450 in Mammals of South America (Gardner, A. L., ed.). Vol. 1. Marsupials, xenarthrans, shrews, and bats. University of Chicago Press, Chicago. Illinois, USA.

Díaz, M. M., S. Solari, L. F. Aguirre, L. M. Aguiar, and R. M. Barquez. 2016. Clave de identificación de los murciélagos de Sudamérica. Publicación Especial No. 2. Programa de Conservación de los Murciélagos de Argentina. Tucumán, Argentina.

ESRI. 2014. ArcGis 10.3 Enterprise Deployment, an Esri technical paper. USA.

Gervals, H. 1841. Mammifères. Pp. 1 - 68 in Zoologie. (Eydoux, J. F. T., and L. F. A. Souleyet, eds.). In Voyage autor du Monde exécuté pendant les années 1836 et 1837 sur la corvette La Bonite commandée par M. Vaillant. Paris: Arthus Bertrand, 4: xl+334 pp.; Atlas: plates 1-12 (Mammifères). Paris, France.

Giménez, A. L, N. P. Gianninı, M. I. Schiaffini, and G. M. Martin. 2015. Geographic and potential distribution of a poorly known South American bat, Histiotus macrotus (Chiroptera: Vespertilionidae). Acta Chiropterologica 17:143-158.

HiLL, J. E., AND D. L. HarRISON. 1987. The baculum in the Vespertilioninae (Chiroptera: Vespertilionidae) with a systematic review, a synopsis of Pipistrellus and Eptesicus, and the description of a new genus and subgenus. Bulletin of the British Museum (Natural History), Zoological Series 52: 225305.

Koopman, K. F. 1978. Zoogeography of Peruvian bats, with special emphasis on the role of the Andes. American Museum Novitates 2651:1-40.

Lee, T. E., S. F. Burneo, T. J. Cochran, and D. Chávez. 2010. Small mammals of Santa Rosa, southwestern Imbabure Province, Ecuador. Occasional Papers of the Museum of Texas Tech University 290:1-14.

Linares, O. J., AND E. Zavala. 2018. Refugios diurnos del murciélago Eptesicus innoxius (Chiroptera, Vespertilionidae), en la provincia de Guayas, Ecuador. Investigation Research Review 11:29-40.

Loaiza, C. R., and V. Pacheco. 2017. Modelamiento predictivo, distribución geográfica y estado de conservación de Tomopeas ravus Miller, 1900 (Chiroptera, Molossidae). Revista Peruana de Biología 24:193-198.

Merow, C., M. J. Smith, and J. A. Silander. 2013. A practical guide to Maxent for modeling species' distributions: what it does, and why inputs and settings matter. Ecography 36:1058-1069.

Ministerio de Ambiente del Ecuador. 2013. Sistema de clasificación de los ecosistemas del Ecuador continental. Proyecto mapa de vegetación del Ecuador, Subsecretaria de Patrimonio Cultural. Ministerio de Ambiente del Ecuador. Quito, Ecuador. 
Ministerio del Ambiente. 2015. Mapa nacional de cobertura vegetal: memoria descriptiva. Dirección General de Evaluación, Valoración y Financiamiento del Patrimonio Natural. Lima, Perú.

Morales, N. 2012. Modelos de distribución de especies: Software Maxent y sus aplicaciones en conservación. Revista Conservación Ambiental 2:1-3.

Olson, D. M., And E. Dinerstein. 2002. The Global 200: Priority ecoregions for global conservation. Annals of the Missouri Botanical Garden 89:125-126.

Pacheco, V., R. Cadenillas, S. Velazco, E. Salas, and U. Fajardo. 2007. Noteworthy bat records from the Pacific Tropical rainforest region and adjacent dry forest in northwestern Peru. Acta Chiropterologica 9:409-422.

Pacheco, V., R. Cadenillas, E. Salas, C. Tello, and H. Zeballos. 2009. Diversidad y endemismo de los mamíferos del Perú. Revista Peruana de Biología 16:5-32.

Phillips, S. J., R. P. Anderson, And R. E. Schapire. 2006. Maximum entropy modeling of species geographic distributions. Ecological Modeling 190:231-259.

Phillips, S. J., AND M. Dudík. 2008. Modeling of species distributions with Maxent: new extensions and a comprehensive evaluation. Ecography 31:161-175.

Romero, V. 2018. Eptesicus innoxius. In amíferos del Ecuador. Versión 2018.0. (Brito, J., Camacho, M. A., Romero, V., andA. F. Vallejo, eds.). Museo de Zoología, Pontificia Universidad Católica del Ecuador. https://bioweb.bio/faunaweb/ mammaliaweb/FichaEspecie/Eptesicus\%20innoxius, Downloaded on February 12, 2019.

Simmons, N. B. 2005. Order Chiroptera. Pp 312 - 529 in Mammal species of the world, (Wilson, D. E., and D. M. Reeder, eds.). The Johns Hopkins Press. Baltimore, U.S.A.

Stockwell, D., And D. Peters. 1999. The GARP modelling system: problems and solutions to automated spatial prediction. International Journal of Geographic Information Science 13:143-158.

TiriRA, D. G. 2008. Mamíferos de los bosques húmedos del noroccidente de Ecuador. Ediciones Murciélago Blanco y Proyecto PRIMENET. Quito, Ecuador.

TiriRA, D. G. 2017. Guía de Campo de los mamíferos del Ecuador. Editorial Murciélago Blanco. Quito, Ecuador.

TiriRA, D. G., AND J. P. Carrera. 2011. Murciélago marrón del Pacífico (Eptesicus innoxius). Pp. 206 in Libro rojo de los mamíferos del Ecuador (Tirira, D. G., ed.). Fundación Mamíferos y Conservación, Pontificia Universidad Católica del Ecuador y Ministerio del Ambiente del Ecuador. Quito, Ecuador.

Velazco, P., And L. Aguirre. 2016. Eptesicus innoxius. The IUCN Red List of Threatened Species 2016. < <www.iucnredlist. org >. Downloaded on 12 May 2017.

\section{Associated editor: Sergio Solari}

Submitted: November 19, 2018; Reviewed: December 11, 2019;

Accepted:May 5, 2019; Published on line: November 26, 2019. 


\section{Appendix 1}

Locality records for Eptesicus innoxius in Ecuador and Perú used in potential distribution analyses: ECUADOR, Bolívar: Barraganete, $3 \mathrm{~km}$ al suroeste de Echeandía, $237 \mathrm{~m}$ (-1.45, -79.299; MEPN 1840) $\bigcirc$; Cotopaxi: Hacienda Hnos. Cabrera, 195 m (-0.935, -79.246; QCAZ 18177 - 18178) q $q$; El Oro: Cerro Chiche (Piñas), 547 m (-3.766, -79.647; TTU 102399) సं; R. E. Arenillas (Palmales), 68 m (-3.674, -80.108; QCAZ 9063) +; R. E. Arenillas (Quebrada Seca), 709 m (-3.5, -79.766; QCAZ 9776) O; Esmeraldas: Recinto Pedro Carbo, 13 m (0.369, -79.970; MZUGM 00532) q; Guayas: Sector de San Ramón (Isla Puná), 8 m (-2.933, -80.133; AMNH 66822, 66825) 30 ; Sector de Salitre, 8 m (-1.834, -79.815; USNM 534270) ; ; Sector de Yaguachi, 4 m (-2.116, -79.683; EBD 12631 - 12632, 12636 - 12649); B. P. Cerro Blanco (Sector Manantial), 34 m (-2.180, -80.031; TTU - 103325) O; La Pólvora (Isla Puná), 30 m (-2.764, -79.915; QCAZ 9067 - 9069,

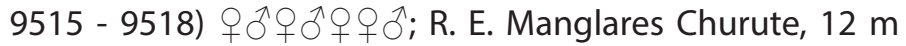
(-2.509, -79.744; QCAZ 9073) O๋; R. E. Manglares Churute (Cerro Cimalón), 23 m (-2.426, -79.561; TTU 103514 - 103516, 103521 - 103522) 웋ํ우; R. E. Manglares Churute (Cerro Pancho Diablo), $11 \mathrm{~m}$ (-2.420, -79.631; TTU 103670) ठै; El Retiro (río Pucón), 39 m (-1.312, -79.943; QCAZ 12654) ô; B. P. Prosperina, 217 m (-2.149, -79.978; MZUGM 00582) q; B. P. Cerro Blanco, 276 m (-2.142, -80.086; MZUGM 00443) స; B. P. Cerro Blanco, 64 m (-2.179, -80.021; MZUGM 00489) 3; Cerro del Muerto, 41 m (-2.643, -80.340; MZUGM 00699) 3; Área Nacional de Recreación "Isla Santay", 7 m (-2.211, -79.849; MZUGM 00727 - 00729) qổ 9 ; Loja: Río Pindo, 1021 m (-4.016, -79.667; AMNH 47226 - 47228, 47230 47232) 우수웅ํ수; Had. Casanga, 990 m (-4.017, -79.750; AMNH 47234) 9 ; Valle del río Casanga, 1458 m (-4.083, -79.75; AMNH 257589) q; Las Cochas del Almendro, 550 m (-4.194, -80.270; QCAZ 11835) ôं; Los Ríos: 1.5 km al sur de San Carlos, en la vía Quevedo - Babahoyo, 76 m (-1.130,

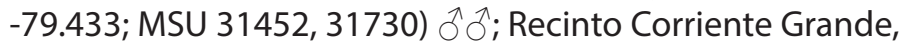
sobre el río Baba, 88 m (-0.722, -79.455; QCAZ 8897, 8904) స. ; Cerro Cacharí, 33 m (-1.779, -79.463; MZUGM 00491, 00496, 00606) $\widehat{\jmath}+q$; Santo Domingo: La unión del Toachi, 815 m (-0.321, -78.952; QCAZ 17184) Ō. PERÚ, Lambayeque: Puerto Etén, sector costero cerca de Chiclayo, 5 m (-6.926, -79.864; USNM 103923 - 103927) 우우우우; Sector de Motupe, $132 \mathrm{~m}(-6.15,-79.716 ;$ FMNH 81033) $\circ ; 12$ km al norte de Olmos, 150 m (-5.841, -79.783; LSUMZ 27258

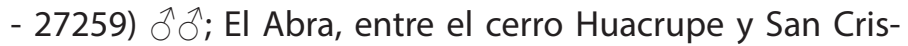
tóbal, 127 m (-5.821, -79.936; MUSM 34642 - 34644) 우우; Piura: Amotape, $18 \mathrm{~m}$ (-4.883, -81.015; MNHN 6987) ठో; 4 millas al oeste de Suyo, 418 m (-4.516, -80.066; TCWC 12751 - 12753) 웅; Coto de Caza "El Angolo" (La Falda), 947 m $(-4.265,-80.673 ; \mathrm{NCl}, 2007) \hat{o}^{\uparrow} ; 44 \mathrm{~km}$ al norte de Olmos, $1517 \mathrm{~m}(-5.585,-79.586$; LSUMZ 21309, 21310, 21816) 우 $\widehat{0}$; Laguna Ñapique, 13.3 km al este de Séchura, 9 m (-5.538, -80.703; MUSM 20895) +; Pampa de los burros (El Zural), 735 m (-5.584, -79.668; MUSM 34645) क; Quebrada metida del zorro (El Garabo), 327 m (-5.463, -79.793; MUSM 34646 -
34650) $q$ 수우 $q$; Tumbes: Barrancos, 34 m (-4.114, -80.983; MUSM 20672); Quebrada Faical, $24 \mathrm{~km}$ al sureste de Pampas de Hospital, 727 m (-3.853, -80.280; LSUMZ 24504). 